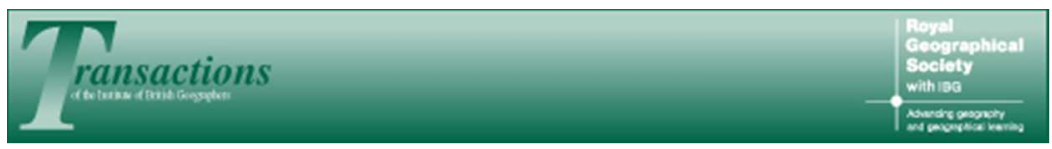

\title{
Sealing Future Geographies: Religious Prophecy and the Case of Joanna Southcott
}

\begin{tabular}{|r|l|}
\hline Journal: & Transactions of the Institute of British Geographers \\
\hline Manuscript ID: & TIBG-RP-Aug-2012-0070.R3 \\
\hline Manuscript Type: & Regular Paper \\
\hline Keywords: & Prophecy, Temporality, Futures, Religion, Faith, Materiality \\
\hline & $\begin{array}{l}\text { This paper seeks to contribute to an emerging debate in human geography } \\
\text { concerning the spatialities of the future, and aims to address a gap in work } \\
\text { on the geography of religion regarding the temporalities of faith. Through a } \\
\text { focus upon religious prophecy, the paper seeks to examine how different } \\
\text { spaces, temporalities, identities, practices and dispositions (both religious } \\
\text { and secular-scientific) are generated through and generate this religious } \\
\text { future. The paper argues that prophecy is a particular form of making the } \\
\text { future, and advances the dual notions cosmic-divine time and preparatory } \\
\text { assured readiness in order to understand and underline this specificity. } \\
\text { Through the example of the prophetess Joanna Southcott (1750-1814) and } \\
\text { an event involving a box of her prophecies publically opened in 1927, it } \\
\text { argues that prophetic space-times presence the future through multiple } \\
\text { and intersecting 'not-yets', hesitancies and assurances. }\end{array}$ \\
\hline
\end{tabular}




\title{
Sealing Future Geographies: Religious Prophecy and the Case of Joanna Southcott
}

\begin{abstract}
This paper seeks to contribute to an emerging debate in human geography concerning the spatialities of the future, and aims to address a gap in work on the geography of religion regarding the temporalities of faith. Through a focus upon religious prophecy, the paper seeks to examine how different spaces, temporalities, identities, practices and dispositions (both religious and secular-scientific) are generated through and generate this religious future. The paper argues that prophecy is a particular form of making the future, and advances the dual notions cosmic-divine time and preparatory assured readiness in order to understand and underline this specificity. Through the example of the prophetess Joanna Southcott (1750-1814) and an event involving a box of her prophecies publically opened in 1927, it argues that prophetic space-times presence the future through multiple and intersecting 'not-yets', hesitancies and assurances.
\end{abstract}

Keywords: Prophecy, Futures, Temporality, Religion, Faith, Materiality. 


\section{Introduction}

The future has been increasingly interrogated by human geographers in the recent past. Work in what has become known as 'future geographies' has sought to examine how the future is thought, how it precipitates certain forms of action in the present, how it is felt through different modes of affect, and how a multiplicity of spaces and places are both produced through and are productive of the future. One of the key insights of this literature is, paradoxically, how the future, the 'not-yet' and what is to become, is made spatially present in the here and now: in other words, how geographies are co-ordinated, brought into being and performed through the making present of the future. At the heart of this endeavour is a critique of a linear and teleological vision of time, and an awareness of how multiple future temporalities circulate in, are given form and are acted upon in the present. The future is thus understood as a temporality that is folded and unfolded in, and through, practices and achievements in the geographical present (Anderson and Adey 2012a).

\footnotetext{
Alongside work on the excess of the event as formation of the (unknowable) future (see Dewsbury 2000), human geographers have taken a particular interest in the logics of anticipation and how the future is variously governed in the present. Notable here is Anderson and Adey's work (2011, 2012b; Anderson 2010) on future securities and
} 
anticipatory techniques, and the logics of planning through scenario enactment (see also Graham 2010 on urban governance and security). In a similar fashion, Evan's $(2010,22)$ investigation into "the assertion that obesity poses a threat to the nation" shows how this claim requires "the future space of the UK to be made 'real' in the present" through techniques of prevention (where an apparently assured future is closed down) and pre-emption (where uncertain futures are prepared for and given form in the present). Evans seeks to analyse how the future is disclosed through statements, calculations, practices and performances and, in-so-doing, how the future is made present so it may be acted upon in the here-and-now. Evan's work also reveals how the future is made present through certain affective capacities, echoing Anderson's arguments about the affective resonances of hopeful dispositions, and their role in sensing and realising the future (2006a, 2006b; 2007; Anderson and Fenton 2008). Here the force of hope presences the future, acting as an imperative to action in the here and now, and filling present geographies with a sense of possibility and potentiality. In a parallel development relevant for this paper, Dittmer's (2007; 2008; 2010) exemplary writing on evangelical sign watching has sought to explore the specifically religious temporalities of eschatological thinking in order to investigate how spatialities of faith and belief produce particular geopolitical narratives and discourses (see also Sanderson 2008; Dittmer and Sturm 2010; and Holloway 2011a; 2011b). With a similar religious focus, Sanderson (2008) has explored how future geographies are realised in the present through hopeful embodied dispositions of a messianic return. ${ }^{1}$ 
However, for the most part, human geographers have been relatively silent on the production, practices and implications of religious or spiritual futures. This paper seeks to address this apparent lacuna and contribute more widely to the discussion of (more secular) future geographies: the aim here is to focus on the specificity and particularity of prophecy as a religious temporality and hence extend both the field of future geographies and the how the future is theorised in the geography of religion. Thus, religious temporalities of prophecy are produced and performed through a distinct set of characteristics and processes that distinguish it from other 'present-futures,' such as the forms of pre-emptive and precautionary action discussed by Anderson, Adey and others. The specificity of the prophetic encounter and event can therefore lend further insight into how the future is disclosed and acted upon in the present. This difference is posited here by exploring what can be deemed geographies of cosmic-divine time and preparatory assured readiness as modes of disclosing and attending to the future.

\author{
A key question for this paper is how religious prophecy, as a way of presencing the \\ future, affords a specific relation to time. To answer this question, the paper begins \\ with a brief overview of how prophecy has been analysed and understood in the extant \\ literatures, and how we might begin to differentiate it from other kinds of future. I then \\ seek a close accounting of the work of prophecy and the prophetic event in a number \\ of ways: how prophetic spatialities are performatively brought into being; how the \\ spatio-temporal generation of prophecy is achieved through and affords different \\ subjectivities; and how prophecy works with, generates and surfaces from different
}


(affectively charged) milieus of religious faith, belief and secular reason. My focus, then, is what prophetic statements and events do, how they are formed through and from different geographies, and how they act as an imperative to (often political) action. Prophecy, as a religious practice, has been mostly associated with 'religions of the word' (Christianity, Judaism and Islam) and oracular prophesying (Shepherd and Shepherd 2009). In this paper spoken utterances and texts take their place alongside more embodied, sensual and material forms as active constituents of prophetic events, and the spaces and places they generate. In what follows I seek explore these foci and provide answers to these questions through the life of a particular prophet and, more extensively, a specific prophetic event associated with their life and mission. Examining this prophet and specific event of prophecy allows existing work on the subject, alongside work on the geography of the future and religion, to be enhanced and developed.

\section{Understanding Prophecy}

For the purpose of this paper prophecy will be defined as "a divinely inspired utterance or discourse" and hence the prophet as "one who speaks for God or for any deity, as the inspired revealer or interpreter of his will" (Taithe and Thornton 1997, 1). This definition distinguishes prophecy from the more secularised and general sense of the prediction of future events (for example, the more prosaic future-gazing of Paul the 
Octopus). Accompanying the prophet who directly receives divine messages are those who interpret and make sense of the given prophetic discourse - those sign watchers and historical interpreters endowed with the 'gift of discernment'. Although this paper concerns itself mostly with the religious prophet who claims to channel the word of God, those who made sense of their divine inspiration are central to the broader understanding of the prophetic event studied here.

As Shepherd and Shepherd $(2009,735)$ state the "activity of broadcasting revelations attributed to a transcendent source, have been fundamental and reoccurring phenomena in the history of religion". The prophetess explored here belongs to the Christian tradition, yet prophecies are known in Judaism, Islam, Native American spirituality and, as we have seen, the Mayan and Aztec civilisations so often appropriated today by the New Age (Sitler 2006). The majority of Christian prophets concern themselves with the advent of the millennium and Christ's thousand year reign, and hence could be argued to presence a particular future temporality that involves an apocalyptic battle between Good and Evil, a period of tribulation, and a golden age for the saved. Prophecy then, in this Christian millenarian form, is often characterised as being either predictive wherein, as Thompson $(2005,9)$ describes, "the prophet nails his or her colors to the mast by announcing when the apocalypse is coming", or "explanatory millenarianism, which is organized around the identification of "signs of the times'"'. 
The historical, sociological and anthropological literature on prophecy broadly adopts two interpretative approaches. First, prophets and prophetic movements are often analysed as a functional outcome of, or caused by, their social and economic context. As O'Leary $(1994,8)$ points out, key studies of millenarianism and prophesying, such as those by Hobsbawn (1959), Worsley (1968) and Cohn (1970, 1993), "look for economic explanations of apocalyptic movements [and find] in them a primitive response to material depravation and the social dislocation of modern industrial life". Yet, as Harrison $(1979,38)$ states "It is easy to say that prophets' actions are functional phenomena related to the needs of a particular historical situation, and that as the context changes so does the behaviour. But this does not take us very far". As such, whilst it is important to situate a prophetic movement in its time and place, studies which view prophecy as a function of context lack the close accounting of the performative labour and practices involved in prophetic movements, and how they maintain their consistency.

Furthermore, one must recognise that prophecies are practical utterances and are often political languages that offer a critical stance towards state institutions and ongoing political conflicts (Taithe and Thornton 1997; Urban 2006). Particularly in their broadly conceived folk and anti-intellectual form, prophecy has offered subversive and resistant discourses for centuries (particularly anti-clerical discourses, as the Quakers exemplify see Mack 1992): from the English Civil War (wherein end-time anticipation was extensive) and the French Revolution, colonial rule and apartheid (Megoran 2013), 
through to the Cold War and the 'War on Terror', millennial and prophetic movements often take on a political and geopolitical (sometimes more secularised) character particularly when a nation's apparent divine destiny is involved (Boyer 2010). Here the Front National and Jean Marie Le-Pen's belief in the 'second coming' of Joan of Arc as the saviour of France would be illustrative (Davies 1997).

As a bridge between the earthly world and the divine, the prophet is produced as "an authorial identity that denies the involvement of the earthly body of the prophet, except as a tablet upon which the source of their inspiration can inscribe the prophecy" (Taithe and Thornton 1997, 8). Yet, by the end of the nineteenth century, and into the twentieth, prophecy became a focus for psychological explanations and the import of the prophet as divinely inspired began to decline (echoed by a move in more 'mainstream' Christian traditions against predictive prophesying). As Hayward (1997, 175) explains, this psychological approach shifted the relationship to time that prophecy enacted:
"Through the rhetoric and perspectives of the new psychology, the meaning of prophecy was reversed. It was no longer seen as a revelation of the future but was instead interpreted as the eruption of a forgotten past."

Repressed desires, anomie and the power of the unconscious took the place of divine agency as the author of the prophetic utterance. As this psychological explanation 
gained ascendency, the body and psyche of the prophet were placed in service of the unconscious or non-conscious. Indeed, as Pile (2012) has explored, late nineteenth century psychologists and psychoanalysts held a fascination in 'occult' phenomena such as telepathy, telekinesis and clairvoyance as a form of future-gazing. Rather than viewing these abilities as the product of a transcendental author or other supernatural processes, psychology deemed them "norma/human" or sometimes 'supernormal' abilities generated through non-conscious states of minds (Pile 2012, 49, original emphasis). With these psychological understandings the de-authored, in service of the divine, prophet became re-authored through emerging theories of the (sometimes extraordinary) mind.

The second dominant interpretative approach to prophecy is to explore how groups make sense of predictions that fail to happen and hence the problem of 'cognitive dissonance': the tension between belief, the apparent assurances of prophetic doctrine, and actual experience (Thompson 2005). What then happens to an individual or group when the predicted date for the Rapture, Armageddon or the Second Coming arrives and, for example, the forces of Good and Evil fail to enter into an apocalyptic battle or the saviour fails to return to instigate his thousand year reign? Drawing on and responding to Festinger et al's (1956) seminal study of failed prophecy amongst a small apocalyptic UFO cult, this can result in firstly a rationalisation of why prophecy fails and secondly a reaffirmation, often through increased proselytising, of the original mission of the group. The rationalisation of the failed prophecy can sometimes involve what has 
been deemed a 'spiritualisation', where what was meant to happen actually did occur, but on an invisible, heavenly plane of existence (Dein and Dawson 2008).

One way in which commentators have sought to move beyond the inherent functionalism of earlier studies, the focus on cognitive dissonance, or psychological explanations, is to explore the language of prophecy. In particular, O'Leary's rhetorical analysis understands prophecy as an event of discourse that has practical effects upon its audience. Here, prophecy does something: as Harrison (1976, 12, added emphasis) argues, the prophetic message "is an attempt to systematize all the manifestations of life in the light of the need for salvation, and is essentially practical, even at the expense of logical constituency". In particular, the message generates certain identities, communities and encounters with and in relation to time. As O'Leary (1994, 16-17, original emphasis) explains:

"Apocalyptic [and prophetic] discourse is about time; it places the rhetor and the audience (and by extension, the whole human community) into a context of cosmic time where the judgment of history is revealed as imminent...For if apocalyptic arguments are again salient in today's public discourse, it is surely not because they have proved their validity by withstanding the test of time; rather, they have managed to survive the repeated disconfirmations of time's passage by a process of discursive reformulation that continually ties apocalypse to the present by reconceiving the relationship of past and future" 
Such discourses about time, and its constant reformulation, can produce both religious and secular communities, political identities and encounters.

Moreover, the disclosure of the future by prophets and in prophetic events involves a specific relation to time: prophecy for the faithful entails a qualitative assurance of certainty. As such, a prophet does not reveal an open, uncertain or unpredictable future, but one where the defined and determined will of a deity is disclosed in the present. Here time is not "an open set of endless possibilities" of which different institutions and agencies seek to anticipate through action in the present, but one which is defined by transcendental, divine and cosmically sourced certainties underscored by faith (Anderson 2010: 792). What we can call the cosmic-divine time of prophecy therefore involves the revelation of an assured telos. For many of the Christian faith this is revealed in biblical prophecies of Grace realised through the Resurrection and the (imminent) Second Coming of Christ. Furthermore, in distinction to the forms of anticipatory action described by Anderson (2010), this future is not "tensed on the verge of catastrophe" (unless one counts the period of the Tribulation see Dittmer 2007; 2008; 2010), and redolent with threats and dangers, but one suffused with the promise and guarantee of a 'golden age' for the saved. Prophecy therefore carries with it a distinct set of characteristics that coalesce around the speaking and evocation of a transcendental author whose word, plan and promise is seemingly certain, guaranteed and given. In this light, the 'spiritualisation' involved with 
cognitive dissonance is a form of reaffirmation of the certainties of cosmic-divine time: faithful communities and the future are made sure again through the insistence on a transcendental temporality and spatiality.

In the next sections of the paper, I exemplify this notion of cosmic-divine time and how it is performed and practiced. I illustrate how prophecy and prophetic events perform certain relations and produce certain spatialities and temporalities, such as the space of the encounter with the prophet, their legacy or their texts, and visions of space both this-worldy and transcendental (Collins 1984). The focus here is on the anticipation of a promised future that is registered and played out in (geo)political, embodied and material practices, and how communities and identities become differently politicised and brought into relation through the performative presencing of the cosmic-divine space-times of prophecy. To illustrate these processes, I examine the famous eighteenth and nineteenth century prophetess Joanna Southcott (1750-1814). My intention here is not to dwell too much on Southcott's life per se, but to look at an event of prophecy that happened 113 years after her death. However, some detail of her life and the movement that grew up around her is necessary in order to make sense of this later event of prophecy (for the most part this account of Joanna Southcott is derived from Brown 2002, 2003; Harrison 1979; and Lewis 1997). 


\section{Joanna Southcott}

Joanna Southcott was born in April 1750 near Ottery St Mary in East Devon, the fourth surviving child of farming couple William and Hannah Southcott. William and Hannah were a pious and devote Christian couple who brought Joanna up in a similar manner (her father read a chapter of the Bible to her daily). Joanna spent her early years on the farm and in nearby Gittisham, and then became a domestic servant and upholsteress in various homes in Exeter and the surrounding area. However, it was events at the age of 42 that transformed her life and gave her a long-lasting historical renown.

In 1792, Joanna experienced a 'Strange Visitation' of an inner voice she described as the 'Spirit of Truth'. As she describes in her first book, The Strange Effects of Faith $(1801,5):$

"...in 1792, I was strangely visited, by day and night, concerning what was coming upon the whole earth. I was then ordered to set it down in writing. I obeyed, though not without strong external opposition; and so it has continued to the present time."

Southcott became slowly convinced that her 'Spirit of Truth' was the direct voice of God - the spirit told her "Whatever I put into thy mouth, I will do upon the earth" $(1801,6)$. 
This conviction became stronger after she correctly prophesised crop failure to her sister who had initially argued "As to the dearth of provision you speak of, you are wrong" $(1801,5)$. Her sister also stated "You say there will be a war. Who shall we go to war with? The French are destroying themselves...as to the distresses of the nation, you are wrong there; for England was never in a more flourishing state than it is at present" $(1801,5)$. Joanna's geopolitical prophecy came to fruition when in 1793 France declared war on Great Britain.

Others were less convinced: a local Methodist preacher John Leach, to whom Joanna had been instructed to seek guidance, listened to her claims and then responded, "It comes from the Devil; for not one thing you have mentioned will come to pass" (1801, 6). Yet despite such rebuttals Southcott continued to seek acceptance from various preachers and clergy of her status as a prophetess. Using her savings she managed to get a thousand copies of The Strange Effects of Faith printed. The book gained some influence and in 1801 seven men (including Anglican clergymen) invited by Southcott arrived in Exeter to examine her writings and judge her powers of prophecy. They left convinced and agreed that she was "pious, honest, industrious and, above all, quite sane" (Brown 2002, 102).

Joanna was taken to London and the 'Seven Stars', as the group of men were named, promoted and publicized her prophecies far and wide, including a thousand letters to MPs. Yet her own doubts over the veracity of the voice she heard and her status as 
prophet continued. These misgivings were accredited to the power of Satan; so for seven days she isolated herself in Portman Place in London to do battle with the Evil One. ${ }^{2}$ Joanna was victorious and in turn her spirit ordered her to fast for 40 days. In a similar manner to the Quakers a century or so earlier, Southcott's fasting can be seen as an attempt to "dissolve the habits, passions, gestures, and little secret sins that made them who they were" (Mack 1992, 7). Here we can contend that through a series of ritualistic technologies of the self the individual is made and determined as prophetic. Through faithful practice Southcott trained herself to accept the prophetic event and to deny her "will and acknowledged past" through transforming herself as a "passive instrument in the service of the divine" (Hayward 1997, 64). Moreover, through ritual and faithful practice, she made present a prophetic cosmic-divine future as certain. Indeed, Southcott described how through fasting she was given over to further revelatory experiences and prophetic encounters that have a determined future (Hayward 1997).

Southcott began to gather a movement of believers and followers around her. From 1802 , believers were invited to become one of 'The Sealed' by signing a statement renouncing Satan. The statement was then signed by believer and prophet, folded and secured by a wax impression of Joanna's seal. In this way the individual became a 'sealed servant of the Lord' and had signed 'for Satan's destruction'. The practice of 'sealing' became popular: the poor viewed them as 'passports to heaven' and carried them as good luck charms, soldiers at Waterloo carried them for protection (see also 
Hill 2007), and a hidden economy developed in their exchange. With Southcott estimating 14,000 people had been sealed by 1807 this faithful practice made present and affirmed the promise of the cosmic-divine future (such technologies hint at the affordance of prophetic materiality which will be discussed in the next section).

Southcott's writings were prodigious: as Harrison $(1979,88)$ notes, "in the twenty-two years between 1792 and her death in 1814 she produced sixty-five pamphlets, containing some 4,500 pages and perhaps twice as much in unpublished manuscripts". From early on in her career as a prophetess, Joanna had taken to sealing some of these various writings - such as those read by and examined by the 'Seven Stars' that visited her in Exeter in 1801. Before leaving, the Seven had placed these sealed writings in a box that was given to one of them, the distinguished engraver William Sharp, who took it back to London with him. He recorded how:

\footnotetext{
"I had a large case made which enclosed the whole box, for the cords around it were sealed with seven seals and I put two between the box and the case, that the seals might not be broken" (William Sharp cited in Lewis 1997, 91)
}

\author{
The faithful asserted that once opened the contents of the box would prove Southcott's \\ prophecies true. Hence the sealing of her word echoed the sealing of the followers \\ described above: both involved the making present of a cosmic-divine future; both
}


involved securing a future assured by a transcendental author divined by the prophetess. The future and Southcott's veracity were literally sealed.

This box will become central to the prophetic event I wish to examine later in the paper. However, I wish to place it aside for the moment in order to recount the last and other famous period of Southcott's life. In 1796 Southcott's spirit informed her that she was to be the bride of the Lamb as described in Revelation 19. As such, Christ was revealed to be her spiritual husband. Furthermore, from approximately the early 1790 s, Southcott identified herself as the 'woman clothed with the sun' of Revelation 12: 1 which states, "and there appeared a great wonder in heaven; a woman clothed with the sun, and the moon under her feet, and upon her head a crown of twelve stars." Perhaps even more remarkably in 1814, her 'Spirit of Truth' announced to her "This year, in the sixty-fifth year of thy age, thou shalt have a Son, by the power of the Most High, which if they receive as their Prophet, Priest, and King, then I will restore them to their own land" (Southcott 1814, 4). In other words, she was to give to the world the second virgin birth of the messiah, identified by Southcott as Shiloh the 'man-child' of Revelation 12: 5.

With a mixture of joy and incredulity believers and others gathered in London to await the birth. Those certain in the future bought clothes for the infant and an elaborate cradle made of satin wood was made for a cost of $£ 200$. Meanwhile, the unconvinced press had a field day pouring scorn on Joanna and her follower's belief in the 
pregnancy: she was a virgin and aged 64 . Yet, seventeen doctors, upon examining her, agreed that she was with child. Thus the practice and performance of disclosing the future was multiple in this event of prophecy. A series of relations of faith and non-faith were performed leading up to the 'birth': some doubted, some were hesitant, some were certain in their scepticism. Those disposed to a faithful certainty, acting on the guarantees of Southcott's extant veracity as prophet, prepared for the event with a faithful assurance (Anderson 2010). Such a mode of attending to the future we might call a preparatory assured readiness. the faithful were on the verge of and ready for the certain futures to come.

The Southcottians argued that Shiloh would be born in the autumn of 1814 . In November the child had not been born. Southcott began to have doubts in her own pregnancy as the physical signs subsided, but others around her at number 38 Manchester Street, Marylebone did not lose faith and remained assured. Yet Joanna grew increasingly ill and died at 4 am December $27^{\text {th }} 1814$. Still her followers did not lose their faith, keeping the body warm as they expected her to be physically resurrected on the fourth day. When this failed to happen they allowed a Doctor Reece to perform an autopsy on the body who found no sign of pregnancy.

Some followers fell into disbelief, their preparatory assured readiness undermined by the arrival of an un-promised future. Others maintained their convictions, certain that the promised future that they had faithfully prepared for and made present had actually 
occurred. As such this moment of cognitive dissonance was 'spiritualised' by many believers: a widespread belief amongst her followers was that Shiloh had actually been born, but on a spiritual realm and taken straight to heaven as stated in Revelation 12:5: 'And she brought forth a man child....and her child was caught up unto God, and to his throne.' The faithful remained assured that the promised and certain future had indeed happened through, paradoxically, the promise of a past biblical prophecy.

In overview, the Southcottians as a movement were best described as loose federation of groups who had faith in her mission. This organisational set-up affected the continuation of the movement after Joanna passed away. As Harrison $(1979,112)$ argues:

"The weakness of the organization became apparent on the death of Joanna. Following the traumatic shock of the Shiloh tragedy came various conflicting claims to inherit Joanna's mantle, and at this point the institutional structure was not strong enough to prevent disintegration"

Today the major group to claim lineage to Southcott are The Panacea Society who were brought together in the early part of the twentieth century through a common interest in the life and work of Joanna. In 1916, one of the group, Mabel Barltrop, began herself to receive messages from God directly. Then, as the society states on its website "It was eventually realised in February 1919 that Mabel was in fact Shiloh, the Child whose 
appearance was foretold by Joanna over a century ago" (The Panacea Society 2007). After her 'visitation' by the Lord she changed her name to Octavia and claimed lineage to seven other prophets including Southcott and Richard Brothers. The certainties of prophetic futures, practiced and realised in the past, were once again made present. And as we shall see, The Panacea Society made present and prepared for further assured futures.

\section{Materialising Prophecy}

On April $28^{\text {th }} 1927$, the ghost hunter and 'psychic detective' hunter Harry Price arrived at his two year old National Laboratory of Psychical Research to receive the news from his secretary that "Joanna Southcott's box had arrived". The box (weighing eleven pounds and measuring 12.5 inches long, 9.5 wide and 6 high) was accompanied with a letter from a gentleman claiming that the box had been given to him by a John Morgan, son of a Rebecca Morgan who had been entrusted to safeguard it by Southcott on her death-bed. The letter stated:

"I do not know how many boxes Joanna left, and there are bound to be spurious ones, but the history of the one I am sending you can be traced from the time the dying hand of Joanna entrusted it to the trembling Rebecca until it was handed to me by another dying hand..." (Price 1933, 288-289) 
The box was made of walnut and was "much stained with age" (Price 1933, 290). On it was a plate engraved with the initials "I.S." (Iesu Christi) and it was encircled with rusty steel bands and silk tapes protected by seals. Via Price's account of the box and the ensuing events surrounding it, here I wish to examine how different and intersecting modes of temporality are performed in the encounter with the 'prophetic' box and how these temporalities are generative of and act to coordinate certain relations, dispositions and politicised practices of the future.

As discussed in the last section, the sealing of the box (alongside the practice of sealing) can be seen as a performative presencing of a particular comsic-divine future: for the eighteenth and nineteenth century faithful the box sealed the future as given and assured by the transcendent through Southcott the prophet. Followers in the twentieth century stipulated that the opening of the box was only to happen when the nation was in a state of dire need or national emergency. Furthermore, it was only to be opened when 24 bishops called for it and studied Southcott's writings a full seven days leading up to its opening (the 24 bishops corresponded to the 24 Elders of Revelations 4:4). The box, therefore, was said to be central nation's future and survival - its contents and opening was decreed and discerned to have geopolitical ramifications and afford an influence on the space of the nation and its people. Through this decree the faithful presenced their future for the nation, a redemptive future guaranteed by the transcendental word as given to Southcott, if the stipulations were adhered to. 
Indeed, not only was a certain cosmic-divine future and spatiality made present by the existence of the box, its promise was achieved through its prophetic legacy and the veracity of Southcott's 'strange visitation': the affordance of an object's promise was generated in the past, and in turn afforded, materialised and affected a present future and spatiality.

For those in the Panacea Society and other believers in Southcott's status as prophet, the box coordinated a set of communal relations of faith realised as the certain spatial salvation to be afforded by the box's opening. Geopolitical dispositions of assured future salvation resounded and affected relations of those in the present, and simultaneously became an imperative to action in their attempts to have the box opened under the correct spatial conditions. However, the box (akin to Southcott's predicted miracle birth) also coordinated other dispositions and relations that were coloured by an uncertainty tinged with possibility and potential. The capacity of the box to perform these relations owed much to it being closed and its mysterious or potential contents. Hence the ability of the box to afford a promise of potential national salvation was realised through the capacity of unknown or unsure futures to be made present - futures which appear in contradistinction to the faithful certainties of cosmic-divine time. These futures took less certain and divinely assured forms and instead coalesced around feelings of speculative interest, reservation, scepticism and curiosity, as well as outright hostility and cynicism. 
Price, affected by this charge of the unknown, was moved to certain actions, dispositions and judgements: the closed box, and its potential future impact on the space of the nation when opened, had the capacity to act upon and precipitate certain forms of practice in the present. Colouring and politicising his judgement, and organising his practice as scientific, secularised and rational, Price approached the box through a particular modern sensibility:

\begin{abstract}
"When Joanna left strict injunctions that her box was not to be opened except in the presence of twenty-four bishops, I am sure her prophetic soul never visualised the fact that a hundred years later the contents of her box could be examined without opening it. It has been stated that Joanna was an astute psychologist and, as someone remarked, she would have derived considerable satisfaction from the fact that the weapons of secular science - my Laboratory, the X-rays, and photography - would be used to gratify the curiosity of millions of people, 113 years after her death". (Price 1933, 296)
\end{abstract}

The unknown here both precipitates and is approached through a disposition which enacts a politicised temporality of scientific progress that will supersede the religious and seemingly irrational. This eschatological temporality brings forth a desire to know and fix, to open and reveal through technological representation, and thereby coordinates a series of pre-emptive practices of (scientific) anticipatory action. Here scientific dispositions are (re)produced by seeking to make certain that the mere possibility that the box may hold out a divined future is closed down through 
appropriate practices in the present (and here we can see a precursor to the sorts of contemporary practices described by Anderson 2010 and Evans 2010).

Yet this attempt to subsume the unknown to modernity's rational, scientific and secular tenets has as its shadow side the continued possibilities and inherent uncertainties of the mystical and the religious (Saler 2006). Consequently one of the temporalities of presenced by the closed box was one where prophetic futures may potentially be true; this hesitancy and potential then organised and affected a different set of relations and practices. In other words, the mystical and the rational here exist in multiple and contradictory relations to one another, even in the approach adopted by Price: not only did he X-ray the box, but he asked eight mediums and psychics to test their powers through psychometry whereby clairvoyants can sense the history of an object through touch. Price recorded the results of the psychometry:

\author{
"Nearly every medium gave either "manuscripts," "writings," "drawings," or \\ "books." Four mediums gave "another box" or a "smaller box"; two sensed \\ "beads," and two said "seals."" (Price 1933, 295)
}

Therefore, the box of prophecy had the capacity to perform a whole series of relations and afforded the presencing of multiple futures and geographies. As such, prophecy, materialised here through a closed box, produced a passage of time where differing and multiple relations to the future were given form in the present. 
The present-futures brought into being in this event of prophecy were: secularscientific; faithful through the certainty of a prophet and a prophecy's fulfilment; geographical through a nation redeemed; and hesitant that supernatural human powers might be a future or indeed present reality. As one temporality brought into being, Price's secular-scientific practice of X-raying the box displayed:

\begin{abstract}
"An old horse pistol (not cocked), date about 1814; Dice-box; Double-ended fob purse made of steel beads; Coins in the purse; A bone puzzle with rings; Books one with metal clasps; A framed painting or miniature; Pair of gold inlaid, earrings; A cameo or worked pebble." (Price 1933, 296)
\end{abstract}

\begin{abstract}
In so doing, the impress of the unknown was dampened and re-coordinated. The potential futures coloured by uncertainty, insecurity, and hesitancy - in addition to those charged with a fascination emergent from a sense of, and even a shiver of hope for, potential salvation - were refigured as the technical and rational seemed to assume precedence: as Price described, "The X-ray pictures came out exceedingly well, and we all had a good laugh at the articles we saw silhouetted in my radiographs" (Price 1933, 296). Thus the closed box coordinated a series of excessive 'not-yets' as "determination[s] of something that is actual now, i.e. the presence of a qualitative 'more' outside something that has 'become'"' (Anderson 2006a, 696). After its X-ray,
\end{abstract}


amounting to an opening through radiation, these 'not-yets' shifted and coagulated into something otherwise - charges of disdain, derision, amusement and the like.

Despite his scorn, the box, its genealogy and his desire for publicity affected Price enough to respect its history. In a letter to eighty bishops and three archbishops, asking them to attend an 'official' opening of the box, he was moved to state: "One feels, however, a natural reluctance to violating the definite wishes of a dying woman, no matter how misguided...We should like to open the box in circumstances as nearly as possible in accordance with her dying injunctions" (Price 1933, 297). Yet once again the box produced secularised reactions of condescension and amusement, this time from the clergy: the Bishop of Kensington declared that he "did not wish to be a party to provide amusement for a public who would like nothing better than to see a company of bishops the victims of such a hoax" (Price 1933, 299). Prophecy for these religious leaders was something of the past and had no value for the present, let alone the future: here a different set of communal faithful relations were coordinated in the present by a defunct way of envisioning the future. However, the date and place was set for the public opening of the box: Monday, $11^{\text {th }}$ July, 1927 at the Hoare Memorial Hall, Church House, in Westminster. Price advertised the prophetic event in The Times and interest was widespread.

The hall that evening was crowded with the curious. Along with Price, a Professor A.M. Low and the Bishop of Grantham (Dr J. E. Hine) sat on the platform. The latter had 
come along 'out of curiosity', whereas the Professor, who presided over the events, sought to give the event a psychological explanation by making reference in his address to "the particular form of lunacy known as the Southcott movement" (Price 1933, 300). For Low the box was certain to be nothing more than the product of psychological anomie, and hence sought to enact a form of prevention through closing down a potential eschatological future. As Low talked of lunacy, a number of Southcott's supporters in the audience hissed with disdain at his comments.

The mocking by the Southcottians, Lowe's psychology and the Bishop's curious uncertainty thus made present a series of intersecting and divergent future temporalities as the event proceeded. These different futures coalesced and dissipated, as the latest space and time of the Southcottian prophetic encounter was formed: surges of incredulity, credulity, certainty, speculation, fascination, disparagement, faith and rationality patterned the futures made present. Indeed despite, or because of, those who sought to close down the box's potential, an accompanying 'not-yet' future impacted and performed a series of differing relations between those in the space of the hall. As such the impress of past and (near-) future prophetic events charged the space and proceedings, accompanied by a parallel potentiality for disruption (by the Southcottians in particular) and a general force of what was described as "an atmosphere of humorous scepticism [and] the titters of an obviously incredulous gathering" (Brown 2002, 203). The space-time of the hall thus circulated with, and emerged out of, a series of different charges and affective forces coordinated by and 
scored across the materiality of the box, differing dispositions and the impressions of various qualified temporalities, as Price proceeded to cut the metal bands and silk tapes of the box, and prised open the lid with a jemmy.

The Bishop was given the task of revealing the items in the box, one-by-one, as Price described them. The fifty-six items that the box contained brought the recently enacted sense of potential to a mundane yet, as we shall see, partial conclusion. As such, the differing temporalities that impressed on and generated the space of the event materialised through an object's promise, potential or certainty - diffused through the impression of a mundane collection of objects and further materialities: a fob purse, a horse pistol, a night-cap, coins, a lottery ticket, a pair of ear-rings, a dice-cup and a number of books. Any sense or qualitative intensity of hope and expectation were, momentarily, diminished or altered, as an affective as well as cognitive dissonance composed and patterned the room. Furthermore, Price's secular-scientific practice and judgemental disposition was accentuated as he jubilantly described:

\footnotetext{
"The audience, like those on the platform, could not help being struck by the way in which the X-ray photographs had given us clues to the objects found in the box. All our deductions were correct. The pamphlets, books, etc., indicated by shadows, were not clearly discernable in my radiographs, but the solid objects were all as I anticipated." (1933, 301)
} 
Science, it seems, had triumphed over religious claims of eschatological temporalities. ${ }^{3}$ However, this apparent victory for the secular and scientific was (and is) never complete - traces of hesitancy, the force of the unknown and potential 'not-yets' continued and circulated in and formed other space-times after the box's opening. As such, other futures geographies continued to be generated, and persisted to impinge and impress on the present in different ways. A number of these continuing 'not-yets' are worth describing in order to reveal the persistence of the still-potential temporality of prophecy.

First, in his summary of the Southcott event, Price $(1933,301)$ is unable to fully dismiss a still-to-be-realised future presenced by the box:

\begin{abstract}
"It must be admitted that Joanna left a most amazing and heterogeneous collection for the benefit of posterity, and it is a matter of speculation as to what her intention was. Or the objects were perhaps intended to be symbolic."
\end{abstract}

Unknown intentions, therefore, and the possibility of further intentional prophetic symbolism lent insecurity to his account of the now open box. Indeed there is, despite his best judged efforts, a residue of respectful hesitancy in Price's account of Southcott: "That Joanna was a genius of sorts is proved by the fact that nearly 120 years after her death she is still compelling us to expend our time and energy in debating the point whether this 'Bride of the Lamb' was a much-maligned saint or a very astute sinner; an 
inspired prophetess or a cunning charlatan" (Price 1933, 303, emphasis added). Here the 'or' of Price's utterance presences multiple futures, both certain and uncertain.

The second way in which the still-potential of prophecy was maintained involved the authenticity of Price's box itself. The derogatory remarks, accusations and audible hisses from the Southcott's supporters before, during and after the opening were engendered by a belief that Price's box was not the 'real' box. ${ }^{4}$ The difference in dimensions between Price's and the supposedly 'authentic' box were stark: the 'real' box was about 3 foot long, 1.5 feet wide and deep, and weighed about $156 \mathrm{lb}$. Furthermore, according to some biographers of Southcott there is no mention in her archives of the Rebecca Morgan who was supposedly entrusted with the box Price received (see Lewis 1997, 282). Outside Hoare Memorial Hall members of the Panacea Society gave out a leaflet to the audience which stated "The Box of Sealed Writings of Joanna Southcott, prophetess, which the 24 bishops will open, remains and will remain in safe custody until circumstances force the bishops to do what they refuse to do" (Brown 2002, 204). Other followers exchanged letters seeking assurance that the real box was safe. Emily Jowett, the tenth custodian of the 'authentic' box sealed originally in 1802, guaranteed those concerned: it was in her bungalow in Morecambe under the bed she slept in. Indeed, as late as 1971 the Society's then president, 72 year old Mrs. Cybil Cuthbertson, stated Price's "was not the box that was opened. It was just a hoax - nothing to do with us" (Daily Telegraph, $5^{\text {th }}$ September 1971, original emphasis). Once again, prophecy as a presencing of the future emerges out of an assured 
disposition of preparatory readiness: the box's continued existence coordinated and presenced a future, one which the faithful were certain of and ready for.

Subsequently, The Panacea Society continued to call for the box to be opened; they advertised their call on the streets of London, on its buses, often in The Daily Mailand in many magazines such as Tit-Bits (26 ${ }^{\text {th }}$ December 1964) stating "Crime and Banditry, Distress and Perplexity will continue to increase until the Bishops open Joanna Southcott's Box of Sealed Writings". In 1970 the Society remained convinced the box would be opened in the next thirty years (Bedfordshire Times $21^{\text {st }}$ August, 1970); in 1971 the Society argued that "the Second Coming could happen anyway in just 29 years from now, when the Devil's reign will end" (Daily Telegraph $5^{\text {th }}$ September, 1971). And in 1973 they argued that "if the box had been opened in 1939 the holocaust of the last war would have been averted", with the president urging its opening as "We are now in a terrible time of trouble. Strikes, drug-taking, violent crime and pollution are ruining the world. Young people live in fear. Things are getting worse", with their sign-watching literature railing against communists and "socialists ... dominated by Luciferian influences" (Evening Echo $6^{\text {th }}$ August 1973a). Such pronouncements repeatedly affirm the certainties of the cosmic-divine future and the reformed spatialities to be materialised by the redemptive opening of the box, whilst underlining the dispositions of preparatory assured readiness through which the Southcottians maintained their faith. 


\section{Conclusions}

For the most part the literature analysing how future geographies are made present and governed through practices of anticipatory action has explored how the "future is problematized as a surprise" (Anderson 2010: 792). In this paper I have investigated a mode of making present the future that envisions what is to come through certainty and assurance. Thus for those of faith, prophecy presences a future that is determined and guaranteed by divine will as communicated through and by the prophet or prophetess - what I have called here the presencing and performance of cosmic-divine time. This defined telos is performed and made present, in the example analysed here, through utterances, practices such as 'sealing', campaigning and dispositions always on the verge of a certain future of redemption and grace - what this paper has deemed a preparatory assured readiness. This is a mode of making the future present underscored by faithful practice, revelation and an anticipation of certainty. Thus today, if one were to take a walk down Albany Road in Bedford one might still encounter this preparatory assured readiness. For The Panacea Society, custodians of the 'authentic' box in the present, own numbers 12 to 18 on this road. The end house, known as The Ark, is prepared and waiting for the Second Coming after the bishops gather there (Evening Echo $8^{\text {th }}$ August 1973b). Indeed, the Society owns another 20 properties in the town as well as communal gardens, due to Octavia receiving the Divine Order that Bedford was to be the Lord's chosen centre for His Kingdom on Earth. 
Prophecy is characterised by faith in a certain future disclosed by a channel to the divine that organise believers to be ready for and make present its guaranteed promise. Human geographers in their study of future temporalities might usefully explore how this readiness is woven into dispositions of a certain future: how then (akin to the Panacea Society), do believers in prophecy organise in, represent and practice space and place so as to be primed for a certain future, and in-so-doing make that future present? Furthermore, in the example discussed here we have seen how different and often conflicting futures for and of space are made present. This prophetic event and encounter therefore engendered a space and time, where potentiality, actuality and certainty intersected and were often held in constant tension. Whilst a series of preemptive and preventive practices have been detailed (the eschatology of the faithful and the apparent assured practices of science), it has also been noted how the impress of prophecy is one where the always present 'not-yet' can infiltrate dispositions towards the present and the future. There is then an excess to any future-present that can often realign the assurances given by both faith and reason. For those more disposed to the secular, this amounts to a nagging sense that prophets and prophecies might be proven right even if many know that they are, or feel they will be, wrong. In terms of the future of future geographies research, an analysis of how cosmic or religious futures and spatialities might, despite their disavowal, colour or even undermine the assurances of secularism, science and reason (and vice-versa) is something that we might profitably make present in our work. 


\title{
References
}

\begin{abstract}
Anderson B 2006a 'Transcending without transcendence': utopianism and an ethos of hope Antipode 38 691-710
\end{abstract}

\begin{abstract}
Anderson B 2006b Becoming and being hopeful: towards a theory of affect Environment and Planning D: Society and Space 24 733-752
\end{abstract}

\begin{abstract}
Anderson B 2007 Hope for nanotechnology: anticipatory knowledge and the governance of Affect Area 39 156-65
\end{abstract}

\begin{abstract}
Anderson B 2010 Preemption, precaution, preparedness: anticipatory action and future geographies Progress in Human Geography 34 777-798
\end{abstract}

\begin{abstract}
Anderson B and Adey P 2011 Affect and security: exercising emergency in UK civil contingencies Environment and Planning D: Society and Space 29 1092-1109
\end{abstract}

Anderson B and Adey P 2012a Guest editorial: future geographies Environment and Planning A 44 1529-1535. 
Anderson B and Adey P 2012b Governing events and life: 'emergency' in UK civil contingencies Political Geography 31 24-33

Anderson B and Fenton J 2008 Editorial introduction: spaces of hope Space and Culture 11 76-80

Barkun M 2003 A culture of conspiracy: apocalyptic visions in contemporary America University of California Press, Berkeley, CA.

Batty D 2011 Apocalypse not now: the rapture fails to materialise Guardian Online (http://www.guardian.co.uk/world/2011/may/21/apocalypse-not-now-rapture-failsmaterialise) Accessed 25 June 2012

Bedfordshire Times 1970 Doom in 30 years if bishops don't open Joanna's box $21^{\text {st }}$ August [Harry Price Archive, Senate House, University of London: HPG/8/6/4 (xvii)].

Boyer P 1992 When time shall be no more: prophecy belief in modern American culture Harvard University Press, Cambridge, MA. 
Boyer P 2010 Afterword: the geopolitical of end time belief in the era of George W. Bush in Dittmer J and Sturm T eds Mapping the end times: American Evangelical Geopolitics and Apocalyptic Visions Ashgate, Farnham 233- 247

Branigan T, Connolly K and Jones S 2010 Paul the Octopus is Dead - but conspiracy theories are thriving. Guardian Online (http://www.guardian.co.uk/football/2010/oct/26/paul-octopus-dead-psychicworld?intcmp=239) Accessed 25 June 2012

Brown F 2002 Joanna Southcott: the woman clothed with the sun Lutterworth Press, Cambridge.

Brown F 2003 Joanna Southcott's box of sealed prophecies Lutterworth Press, Cambridge

Cohn N 1970 The pursuit of the millennium: revolutionary millenarians and mystical anarchists of the middle ages Maurice Temple Smith Ltd, London

Cohn N 1993 Cosmos, chaos, and the world to come: the ancient roots of apocalyptic faith Yale University Press, New Haven, Conn. 
Collins J J 1984 Apocalyptic imagination: an introduction to the Jewish matrix of Christianity Crossroads Publishing, New York.

Daily Telegraph 1971 Go on then, open the box $5^{\text {th }}$ September [Harry Price Archive, Senate House, University of London: HPG/8/6/4 (iii)]

Davies P 1997 Providence, saviour figures and would-be gods: prophecy and the French in extreme right in Taithe B and Thornton T eds. Prophecy: the power of inspired language in history 1300-2000 Sutton, Stroud 181-201

de Certaeu M 1986 Heterologies: discourse on the other University of Minneapolis Press, Minnesota, MN

Dein S and Dawson L L 2008 The 'scandal' of the Lubavitch Rebbe: messianism as a response to failed prophecy Journal of Contemporary Religion 23 163-180

Dewsbury J-D 2000 Performativity and the event: enacting a philosophy of difference Environment and Planning D: Society and Space $18473-496$

Dittmer J 2007 Of Gog and Magog: the geopolitical visions of Jack Chick and premillennial dispensationalism ACME: An International E-Journal for Critical Geographies 6 278-303 
Dittmer J 2008 The geographical pivot of (the end of) history: evangelical geopolitical imaginations and audience interpretation of Left Behind Political Geography 27 280-300

Dittmer J 2010 Obama, son of perdition?: narrative rationality and the role of the 44th president of the United States in the end-of-days in Dittmer J and Sturm T eds Mapping the end times: American evangelical geopolitics and apocalyptic visions Ashgate, Aldershot 73-95

Dittmer J and Sturm T 2010 Mapping the end times: American evangelical geopolitics and apocalyptic visions Ashgate, Aldershot

Evening Echo 1973a Will the secrets of Joanna's box ever be revealed? $6^{\text {th }}$ August [Harry Price Archive, Senate House, University of London: HPG/8/6/4 (xix)]

Evening Echo 1973b The faithful few who will never see success $8^{\text {th }}$ August [Harry Price Archive, Senate House, University of London: HPG/8/6/4 (vii)].

Evans B 2010 Anticipating fatness: childhood, affect, and the pre-emptive 'war on obesity' Transactions of the Institute of British Geographers 35: 21-38 
Festinger L, Riecken H W and Schachter S 1956 When prophecy fails: a social and psychological study of a modern group that predicted the destruction of the world University of Minnesota Press, Minneapolis, MN

Graham S 2010 Cities under siege: the new military urbanism Verso, London

Hall J R, Schuyler P D and Trinh S 2000 Apocalypse observed: religious movements and violence in North America, Europe, and Japan Routledge, London

Hayward R 1997 From the millennial Future to the unconscious past: the transformation of prophecy in early twentieth-century Britain in Taithe B and Thornton T eds Prophecy: The Power of Inspired Language in History 1300-2000 Sutton, Stroud $160-180$

Harris P 2011 World doesn't end: Californian prophet had no plan B Observer Online (http://www.guardian.co.uk/world/2011/may/22/rapture-harold-camping-end-world) Accessed 25 June 2012

Harrison JFC 1979 The second coming: popular millenarianism, 1780-1850 Routledge and Kegan Paul, London 
Hill J 2007 The story of the amulet: locating the enchantment of collections Journal of Material Culture 12 65-87

Hobsbawm E J 1959 Primitive rebels: studies in archaic forms of social movement in the 19th and 20th centuries Manchester University Press, Manchester.

Holloway J 2011a Tracing the emergent in geographies of religion and belief in Brace C, Bailey A, Carter S and Harvey D eds Emerging Geographies of Belief Cambridge Scholars Publishing, Newcastle 30-53

Holloway J 2011b Spiritual life in Del Casino V, Thomas M E, Cloke P and Panelli R eds A Companion to Social Geography Wiley-Blackwell: Chichester 385-401

Katz D S and Popkin R H 1999 Messianic revolution: radical religious politics to the end of the second millennium Penguin, London

Lewis V 1997 Satan's mistress: the extraordinary story of the $18^{\text {th }}$ century fanatic Joanna Southcott and her lifelong battle with the Devil Nauticalia Ltd, Shepperton

Mack P 1992 Visionary women: ecstatic prophecy in seventeenth-century England University of California Press, Berkeley, CA 
Megoran N 2013 Radical politics and the Apocalypse: activist readings of Revelation. Area 45 141-147

McEwan C 2008 A very modern ghost: postcolonialism and the politics of enchantment. Environment and Planning D: Society and Space 26 29-46

Morris R 2006 Harry Price: the psychic detective Sutton Publishing, Stroud

O'Leary S D 1994 Arguing the apocalypse: a theory of millennial rhetoric Oxford University Press, Oxford

Pile S 2012 Distant feelings: telepathy and the problem of affect transfer over distance Transactions of the Institute of British Geographers 37 44-59

Pilkington E 2011 Apocalypse still imminent: rapture now coming in October Guardian Online (http://www.guardian.co.uk/world/2011/may/24/rapture-october-harold-campingapocalypse?INTCMP=ILCNETTXT3487) Accessed 25 June 2012

Price H 1933 Leaves from a pyschist's case-book Victor Gollancz, New York Price H 1974 Confessions of a ghost hunter Causeway, New York 
Saler M 2006 Modernity and enchantment: a historiographic review American Historical Review 111 692-716

Sanderson E 2008 Eschatology and development: embodying messianic spaces of hope Space and Culture 11 93-108

Shepherd G and Shepherd G 2009 Prophecy channels and prophetic modalities: a comparison of revelation in The Family International and the LDS Church Journal for the Scientific Study of Religion 48 743-755

Sitler R K 2006 The 2012 phenomenon: New Age appropriation of an ancient Mayan calendar Novo Religio: The Journal of Alternative and Emergent Religions 9 24-38

Southcott J 1801 The strange effects of faith with remarkable prophecies (Made 1792, \&c.) of things which are to come: also, some account of my life Exeter Available Online (http://www.thethirdtestament.org.uk/page500.htm) Accessed 25 June 2012

Southcott J 1802 A dispute between the woman and the powers of darkness London Available Online (http://www.thethirdtestament.org.uk/page500.htm) Accessed 25 June 12 
Southcott J 1814 The third book of wonders; announcing the coming of

Shiloh London Available Online (http://www.thethirdtestament.org.uk/page561.htm)

Accessed 25 June 2012

The Panacea Society 2007 Formation and early history of the society

(http://www.panacea-society.org/history.htm) Accessed 25 June 2012

Taithe B and Thornton T 1997 The language of history: past and future in prophecy in Taithe B and Thornton T eds Prophecy the Power of Inspired Language in History 1300-2000 Sutton, Stroud 1-17

Thompson D 1996 The end of time: faith and fear in the shadow of the millennium Vintage, London

Thompson D 2005 Waiting for antichrist: charisma and apocalypse in a Pentecostal Church. Oxford University Press, Oxford

Tit-Bits 1964 Panacea Society Advert. Week Ending December $26^{\text {th }}$ No. 4112 [Harry Price Archive, Senate House, University of London: HPG/8/6/4 (iv)]

Urban H B 2006 America left behind: Bush, the neoconservatives, and evangelical Christian fiction Journal of Religion and Society 8 1-15 


\author{
Volk L 2011 R.I.P. Paul the octopus Anthropology Today 27 24-27
}

Whitesides K 2012 End of the world buffet Fortean Times 285 44-47

\title{
Worsley P 1968 The trumpet shall sound Shocken Press, New York $2^{\text {nd }}$ Edition
}

\begin{abstract}
${ }^{1}$ The social resonance of prophecy through history and popular culture is longstanding. Historically, one can reference the prophecies of, for example, Hidegard of Bingen (1078-1179), William Miller (17821849), the Anabaptists and Taborites of mid-seventeenth century England, Joachim of Fiore (1135-1202) and, more recently, the Branch Davidians under David Koresh, to name but a few (see Boyer 1992; Hall, Schuyler and Trinh 2000; Katz and Popkin; Thompson 1996; 2005). In recent popular culture one can cite, Paul the Octopus (who during the football World Cup of 2010 correctly predicted the results of seven of the German national team's results in the competition; see Volk 2011), the spectrum of speculation concerning the end of the world on the $21^{\text {st }}$ of December 2012 (from New Agers and various soothsayers, to the Hollywood film 2012, directed by Roland Emmerich which grossed $\$ 750$ million; see Whitesides 2012), and the widespread media commentary concerning the evangelical radio preacher Harold Camping and his prediction of the $21^{\text {st }}$ of May 2011 for the Rapture (the moment when the (truly) Christian faithful would ascend to heaven before the divine punishment and suffering of the Tribulation that precedes Christ's second coming and the millennium; see Megoran 2013).

${ }^{2}$ Later published as A Dispute between the Woman and the Powers of Darkness, 1802.

${ }^{3}$ One could read the opening of the box as one, albeit localised and short-lived, event and encounter in the process of disenchantment and the ascendancy of the secular futures - where mystery and the unknown are rationalised away and evidential knowledge supersedes faith, and where a temporality of rational enlightenment and progress is made present and certain (McEwan 2008; Saler 2006).

${ }^{4}$ Some have claimed that Price staged a hoax in order to flush out the 'real' box. Yet Price, to his credit, had never claimed that the box in his possession was the box that the Southcott's followers had so carefully and judiciously guarded - in fact, he had written to the Panacea Society asking them if they wanted the 'Great Box' and any others opened at the same time. Furthermore, he knew that other boxes would be found after he opened his through arguing: "No box, no mystery; no mystery, no 'movement'! The Southcottians without their 'box' would have as much 'go' in them as a motor-car without its engine. It would be unthinkable" (Price 1933, 303). Yet the possibility that Price had himself faked the box he opened remains - was it a fake in order to advertise his newly founded National Laboratory of Psychical Research (see Morris 1996; Price 1974)? If so, then his accusation that "Joanna was a genius in obtaining publicity" is somewhat hypocritical given Price's keen sense of and desire for publicity and stunts (Price 1933, 303; see Morris 1996). Had his ensuing sense of hesitancy toward the box been performed to further his status and career? Or, equally, his statement on the Southcottians could be seen as strangely prophetic in its mirroring of his own course of action and practice.
\end{abstract}

